\title{
Some biochemical changes with laparoscopic cholecystectomy in goat
}

\author{
Al-Abbadi H. A., Helal I. E. ${ }^{*}$ and Taha R. M. *
}

Department of Surgery, Fac. Of Med., King AbdulAziz University Hospital. Director of Experimental Surgery Unit, King Fahd Medical Research Center, King AbdulAziz University, Jeddah, Saudi Arabia. * Dept. of Surgery, Anesthesiology \& Radiology and Clinical Pathology Department, Fac. of Vet Med., Suez Canal Univ., Ismilia, Egypt.
Abstract
Due to the clinical benefits of laparoscopic cholecystectomy over the open procedures 6 adult Saudi Arabian goats have been underwent the work of this study to evaluate the liver function tests before and after Laparoscopic cholecystectomy. Protocol of anaesthesia including intravenous protocol $4 \mathrm{mg} / \mathrm{kg}$ B.W for introducing endotracheal intubation then anesthesia maintained using Isoflurane. Pneumoperitoneum with $\mathrm{CO} 2$ (13-15 $\mathrm{mmHg}$ ) was used in all animals. Blood samples were taken at baseline (preoperatively), two hours, 12 hours, 36 hours 3 days and 7 days postoperatively to measure liver enzymes and some biochemical parameters. All measured enzymes and other biochemical parameter significantly changed after laparoscopic cholecystectomy and returned around their normal values 7 days postoperatively. It could be concluded that laparoscopic cholecystectomy in goat is a safe and successful procedures even with the usage of relatively high intra abdominal pressure.

\section{Introduction}

Laparoscopic cholecystectomy has become a widely used surgical procedure in both human and animal practice. The clinical benefits of laparoscopic over the open procedures had been discussed in the previous literature included less postoperative pain, more rapid return to normal activities, shorter hospitalization, and fewer pulmonary complications (Assalia et al, 1993). According to previous studies it is generally believed by many clinicians that symptoms of postoperative ileus, nausea and vomiting, are reduced by laparoscopic surgery. In addition to rapid recovery after laparoscopic than open cholecystectomy. However, confirmatory data based on physiologic parameters are relatively scarce (Masayuki et al, 1996).

One of the most important hemodynamic changes in laparoscopic cholecystectomy is the transient reduction in hepatic blood flow caused by a pneumoperitoneum (Hasukic et al, 2005) This will lead to degree of hepatic ischemia and elevation of 
liver enzymes (Hasukic, 2005). Alkhilani et al (2011) stated that Laparoscopic subtotal cholecystectomy is available and acceptable alternative to conversion to open cholecystectomy. It avoids the risk of major bile duct injury, and compared with studies of patients undergoing conversion to open cholecystectomy, demonstrates a reduce mortality as well as reduce incidence of wound infections and incision hernia. Cholecystectomy has become gold standard in the treatment of benign gall bladder diseases such as gall bladder stone and cholecystitis (Min-Tan et al, 2003).To our knowledge few literature discussed the effect of laparoscopic cholecystectomy procedures on the to liver function tests in goat. The aim of this work is to evaluate the liver function tests before and after Laparoscopic cholecystectomy in goat.

\section{Materials and Methods}

Six Saudi Arabian native goats have been underwent the work of this study with a body weight ranging from 20 to $25 \mathrm{~kg}$ and their age between 2 to 4 years. Goats were fed alfalfa/grass hay and a commercial diet with free access to water. All animals in this study underwent the same surgical procedures. Food was withheld for 36 hours and water 12 hours preoperatively.

Intravenous propofol at a dose of $4 \mathrm{mg} / \mathrm{kg} \mathrm{B.W}$. was used to facilitate introducing endotracheal intubation for inhalation anesthesia (Reid et.al, 1993). Anesthesia maintained using Isoflurane during the whole period of the surgical procedures. Pneumoperitoneum with $\mathrm{CO} 2$ (13$15 \mathrm{mmHg}$ ) was performed in all animals.

\section{Surgical procedures}

After positioning the anesthetized animals at dorsal recumbent position, the table was positioned in anti-Trendelenburg position; goats were rotated right up so the visceral mass moved downward enable good visualization for the visceral aspect of the liver. Anesthetized goats had four portals for insertion of four trocars, two of them $5 \mathrm{~mm}$ size and the other trocars of $10 \mathrm{~mm}$ size. The first trocar $10 \mathrm{~mm}$ for laparoscope was inserted at the ventral midline just anterior to the umbilicus. The positions of other trocars were inserted at paramedian area as an instrumental portal according to the liver size and convenient access to the gallbladder for the surgeon's preference.

General exploratory laparoscopy was performed initially and none noted. Then the gallbladder was identified and grasped with endograsper. The dissection of the cystic duct and vessels was done using Maryland forceps. The dissection was carried out simultaneously as theses structures adherent to each other in case of goats. After that the duct along with vessels were clipped with titanium clip and divided. The gallbladder were dissected out from its liver bed 
using L-shaped cautery laparoscopic tip, till was removed via a $10 \mathrm{~mm}$ size port. Hemostasis was secured all the way of the procedure. Portals wounds were closed using $2 / 0$ Vicryl in continuous closure then dressed.

\section{Postoperative care}

After complete recovery animals were allowed to return gradually to food and water. Intramuscular Penicillin $20000 \quad$ I.U and streptomycin in a dose of $10 \mathrm{mg} / \mathrm{Kg}$ B.W. were administrated for 5 days postoperatively. Vital parameters including rectal temperature, respiratory rate and heart rate were monitored twice daily for any abnormalities. Surgical stitches were removed ten days postoperatively.Follow-up

examinations were done every day after surgery for determination of any abdominal skin lesions or any abnormal discharges from the 3 portals.

\section{Blood Sampling}

Blood samples was taken at baseline (preoperatively), two hours, 12 hours , 36 hours 3 days and 7 days postoperatively in centrifuges plain tube for serum separation in all groups to measure serum liver enzymes activities and some biochemical parameters.

AST (Aspartate aminotransferase), ALT(Alanine aminotransferase), ALP ( Alkaline phosphtase), Bilirubin (total and direct), total protein and albumin were estimated with spectrophotometer ( Human and Randox UK kits according to the enclosed pamphlet).

\section{Statistical analysis}

The data obtained were analyzed statistically using Block design of analysis of variance (ANOVA) with general linear model procedures (GLM) according to (Hinkelmann \&Kempthorne, 2008). For means separation, Duncan's Multiple Range test (DMRT) (Duncan, 1955) was used. Statistical analysis was run through SPSS (version, 16) for windows (Argyrous, (2007) and Levesque (2007). Results considered significant at $(\mathrm{P} \leq 0.05)$.

\section{Results}

The average time for Laparoscopic cholecystectomy in goat was 25 minutes (range, 20-30 minutes) and the procedures were safe and successful without any major complications during the operation. All goats recovered well from the anesthesia and were moved to the observation room at the same day of surgery where they had returned to normal food and water gradually.

Postoperative observations revealed, signs of mild to moderate abdominal discomfort in four goats and the other minor complication represented by a stitch abscess appeared in one goat which is successfully respond to routine dressing.

Biochemical results (Table 1) revealed that there was significant increase in the total and direct bilirubin after 2 and 12 hours postoperative while no significant 
change after 36 hours, 3 and 7 days. Indirect bilirubin showed significant increase after 12 hours only postoperative while non significant changes in other different periods. Regarding to total protein results there were significant decrease along the experiment. There were no significant changes in albumin after 2 hours only while there was significant decrease after 12, 36 hours, 3 and 7 days. Globulin was significantly decreased all over the experiment duration when compared with control one. Liver enzymes (Table 2) revealed that there was significant increase in AST and ALT activities after 2, 12 and 36 hours and 3 days postoperative while non significant changes after 7 days. Alkaline phosphatase enzyme showed that there was significant increase after 2 hours only while there was significant decrease with other time periods

Table (1): Biochemical parameters with laparoscopic cholecystectomy Mean $\pm S E$

\begin{tabular}{|c|c|c|c|}
\hline $\begin{array}{ll}\text { Times } & \text { Parameters } \\
\end{array}$ & $\begin{array}{l}\text { AST } \\
\text { U/L }\end{array}$ & $\begin{array}{l}\text { ALT } \\
\mathbf{U} / \mathbf{L}\end{array}$ & $\begin{array}{l}\text { ALP } \\
\mathbf{U} / \mathbf{L}\end{array}$ \\
\hline Baseline (preoperatively) & $56.83^{\mathrm{c}} \pm 1.17$ & $19.33^{\mathrm{d}} \pm 0.49$ & $179.0^{\mathrm{b}} \pm 18.37$ \\
\hline Two hours postoperatively & $668.67^{\mathrm{a}} \pm 25.36$ & $66.83^{\mathrm{a}} \pm 3.43$ & $202.17^{\mathrm{a}} \pm 2.33$ \\
\hline 12 hours postoperatively & $589.83^{\mathrm{a}} \pm 73.62$ & $65.50^{\mathrm{a}} \pm 4.13$ & $122.50^{\mathrm{c}} \pm 1.55$ \\
\hline 36 hours postoperatively & $366.67^{b} \pm 27.88$ & $53.33^{\mathrm{b}} \pm 2.93$ & $86.33^{\mathrm{d}} \pm 1.43$ \\
\hline 3 days postoperatively & $133.00^{c} \pm 3.76$ & $31.83^{\mathrm{c}} \pm 0.77$ & $67.50^{\mathrm{d}} \pm 4.10$ \\
\hline 7 days postoperatively & $57.50^{\mathrm{c}} \pm 4.86$ & $15.00^{\mathrm{d}} \pm 0.77$ & $126.67^{\mathrm{c}} \pm 14.73$ \\
\hline
\end{tabular}

Means with different superscripts are considered significantly differ at $(\mathrm{P} \leq$ $0.05)$, while means with the same superscripts are non-significantly differ at $(\mathrm{P}>0.05)$.

Table (2) Liver enzymes activity with laparoscopic cholecystectomy Mean \pm SE

\begin{tabular}{|c|c|c|c|c|c|c|}
\hline Tarameters & $\begin{array}{c}\text { Total Bilirubin } \\
\mathbf{m g} / \mathbf{d l}\end{array}$ & $\begin{array}{c}\text { Direct Bilirubin } \\
\mathbf{m g} / \mathbf{d l}\end{array}$ & $\begin{array}{c}\text { Indirect } \\
\text { Bilirubin } \\
\text { mg/dl }\end{array}$ & $\begin{array}{c}\text { T. } \\
\text { protein } \\
\text { g/dl }\end{array}$ & $\begin{array}{c}\text { Albumin } \\
\text { g/dl }\end{array}$ & $\begin{array}{c}\text { Globulin } \\
\text { g/dl }\end{array}$ \\
\hline Baseline ( & $0.27^{\mathrm{c}}$ & $0.12^{\mathrm{bc}}$ & $0.15^{\mathrm{b}}$ & $1.90^{\mathrm{a}}$ & $1.90^{\mathrm{a}}$ & $5.63^{\mathrm{a}}$ \\
preoperatively) & \pm 0.03 & \pm 0.02 & \pm 0.02 & \pm 0.04 & \pm 0.04 & \pm 0.16 \\
\hline Two hours & $0.57^{\mathrm{b}}$ & $0.23^{\mathrm{a}}$ & $0.33^{\mathrm{b}}$ & $1.83^{\mathrm{a}}$ & $1.83^{\mathrm{a}}$ & $5.25^{\mathrm{b}}$ \\
postoperatively & \pm 0.02 & \pm 0.02 & \pm 0.02 & \pm 0.03 & \pm 0.03 & \pm 0.17 \\
\hline $\mathbf{1 2}$ hours & $1.05^{\mathrm{a}}$ & $0.23^{\mathrm{a}}$ & $0.82^{\mathrm{a}}$ & $1.72^{\mathrm{b}}$ & $1.72^{\mathrm{b}}$ & $5.00^{\mathrm{b}}$ \\
postoperatively & \pm 0.20 & \pm 0.02 & \pm 0.19 & \pm 0.05 & \pm 0.05 & \pm 0.25 \\
\hline 36 hours & $0.52^{\mathrm{bc}}$ & $0.17^{\mathrm{b}}$ & $0.35^{\mathrm{b}}$ & $1.48^{\mathrm{c}}$ & $1.48^{\mathrm{c}}$ & $4.20^{\mathrm{d}}$ \\
postoperatively & \pm 0.04 & \pm 0.02 & \pm 0.03 & \pm 0.06 & \pm 0.06 & \pm 0.04 \\
\hline 3 days & $0.32^{\mathrm{c}}$ & $0.12^{\mathrm{bc}}$ & $0.20^{\mathrm{b}}$ & $1.48^{\mathrm{c}}$ & $1.48^{\mathrm{c}}$ & $4.60^{\mathrm{c}}$ \\
postoperatively & \pm 0.03 & \pm 0.02 & \pm 0.03 & \pm 0.03 & \pm 0.03 & \pm 0.08 \\
\hline 7 days & $0.30^{\mathrm{c}}$ & $0.10^{\mathrm{c}}$ & $0.20^{\mathrm{b}}$ & $1.57^{\mathrm{c}}$ & $1.57^{\mathrm{c}}$ & $5.18^{\mathrm{b}}$ \\
postoperatively & \pm 0.00 & \pm 0.00 & \pm 0.00 & \pm 0.02 & \pm 0.02 & \pm 0.11 \\
\hline
\end{tabular}

Means with different superscripts are considered significantly differ at $(\mathrm{P} \leq$ $0.05)$, while means with the same superscripts are non-significantly differ at (P > 0.05). 
Discussion

During this study we had intended to use a relatively high (standard) intra-abdominal pressure (13-15 $\mathrm{mm} \mathrm{Hg}$ ) which was enough for good visualization of the cholecystectomy field and facilitate easy manipulation of the instruments in the abdominal cavity. on the other hand (Neudecker et al, 2002; Alkhilani et al, 2011) reported that higher intraabdominal pressure may be unsafe procedures at some extent with the respiratory functions and vascular blood flow and they recommended using lowpressure pneumoperitoneum at the lowest possible limit to minimize adverse effects on hepatic portal blood flow.

Usage of standard intra-abdominal pressure may explain why we had the majority of goats in this study suffered from postoperative abdominal discomfort, this results is agreed with (Nakajima et al, 2009) they reported that visceral pain is predominant observation at the first hours postoperatively.

Biochemical results revealed that there was increase in total and direct bilirubin in 2 and 12 hours postoperative and increase the indirect bilirubin after 12 hours only. This results is agree with (Tighe and Brown, 2003) and (Halevy et al, 1994) who reported transient increase in serum bilirubin after

Laparoscopic Cholecystectomy.

Hyperbilirubinemia is caused by hemolysis, stress and truma. The hypoproteinemia, hypoalbuminemia and hypoglobulinemia are also observed and this may be due to hepatocellular injury and thus protein synthesis may be reduced as well as stress (Evans, 2009) also agree with (Ajeel et al, 2012) who reported decline in protein level and hypoalbuminemia in rams.

Results of this study revealed significant increase of ALT and AST. Our results agree with (Halevy et al, 1994 and Ajeel et al, 2012). The elevation may be attributed to alteration in microcirculation, cellular hypoxia and then affect cells membrane and liberate enzymes (Marakis et al, 2006). In addition our results were consistent with that of (Min-Tan et al, 2003) who reported transient elevation of hepatic transaminase occurred after laparoscopic surgery. This may be due to hepatocellular dysfunction secondary to pneumoperitoneum and/or general anaesthesia (Alan, 2007). The results showed significant decrease in the mean values of alkaline phosphatase along the experiment compared with control ones (except transitory increase after 2 hours only). This results agree with (Alkhilani et al, 2011). On other hand our results disagree with (George et al, 2005) who reported non significant changes in ALP were noticed in any groups between the preoperative and postoperative values. Our explanation for decreased ALP that gall bladder is the main source of ALP. 
In conclusion, laparoscopic cholecystectomy in goat is a safe and successful procedures even with the usage of relatively high intra abdominal pressure and give rise to rapid recovery in goat.

\section{References}

Ajeel A, Eesa M, Al- Asadi R, and Alkhilani M,(2012):A comparative study of laparoscopic partial hepatectomy by clamp-crush and ultrasurgical techniques in rams. Iraqi Journal of Veterinary Science Vol.26, supplement IV.131-139.

Alan A. Saber (2007): Non Ominous changes in liver function tests after laparoscopic cholecystectomy. J. Gastrintestin. Liver diseases 16(4).427-428.

Alkhilani M, Eesa J, Saleh S. and Ajeel A. (2011): A comparative study between Laparoscopic complete and subtotal Cholecystectomy in goats. AlAnbar J. Vet.Sci.,(4)59-68

Argyrous, G. (2007): Statistics for Research: With a Guide to SPSS, SAGE, London, ISBN 1-41291948-7.

Assalia A, Schein M, Kopelman D, Hashmonai M.(1993): Minicholecystectomyvs conventional cholecystectomy: a prospective randomized trial. Implications in the laparoscopic era. World J Surg; 17:755-759.

Duncan, D. B.( 1955): Multiple range and multiple $\mathrm{F}$ tests.

Biometrics 11:1-42.

Evans G.O. (2009): Animal Clinical Chemistry: A practical
Guide for Toxicologist and Biomedical Researcher $2^{\text {nd }}$ ed. London, New York.pp 153-159.

George S., George A., VaniaS., Theofilos K.,Nikolaos K., Stavros T. and George K.(2005): Elevation of serum liver enzymes after laparoscopic cholecystectomy. Journal of the New Zealand Medical Association 118(1210)

Halevy M., Gold-Deutch R., Negri M, Lin G., Shlamkovich N., Evans S., Scapa E., Bahar M. and Sackier M.(1994): Elevated liver enzymes and bilirubin levels significant after laparoscopic cholecystectomy in the absence of bile duct injury. ANNALS OF SURGERY 219(4) 362-364.

Hasukic S.( 2005) :Postoperative changes in liver function tests: randomized comparison of low and high-pressure laparoscopic cholecystectomy. Surg Endosc;19:1451-1455.

Hasukic S, Kosuta D and Muminhodzic K.(2005): Comparison of postoperative hepatic function between laparoscopic and open cholecystectomy. Med Princ Pract ;14:147-150.

Hinkelmann, Klaus \&Kempthorne, Oscar (2008): Design and Analysis of Experiments. I and II (Second ed.). Wiley. ISBN 978-0-470-38551-7. Levesque, R.(2007):SPSS Programming and Data Management: A Guide for SPSS and SAS Users, Fourth Edition, SPSS Inc., Chicago Ill. PDFISBN 
1-56827-390-8 SPSS 16.0

Command Syntax Reference 2006, SPSS Inc., Chicago Ill.

Marakis G, Pavlidis T, Ballas K, Rafailidis S, and Psaras K.(2006): Alteration in liver function tests following laparoscopic cholecystectomy Internet J. Surgery 8(1):216-221.

Masayuki H, Matthew J. C., Elias P. M., and Bruce D. S.(1996) : Recovery of Fasted and Fed Gastrointestinal Motility After Open Versus Laparoscopic Cholecystectomy in Dogs. ANNALS OF SURGERY; 223 (4):413-419.

Min-Tan, Feng, X. ;Jun-Shen P. ;Dong-Ming, L. ;Liu-Hua, C.; Bao-Jun, L.; Zhen, Z.; Chen, H. And Chao, X. (2003): Changes in the level of serum liver enzymes after laparoscopic surgery.World Journal of gastroenterology (2): 364-367.

Nakajima, J.; Sasaki, A.; Toru Obuchi, T.; Baba, S.; Nittaand, H.
\& Wakabayashi, G.(2009):

Laparoscopic subtotal cholecystectomy for severe cholecystitis. Surg. Tod., 39 (10): 870- 75.

Neudecker, J.; Sauerland. S.; Neugebauer, E.; Bonjer, H. J.; Fuchs. K. H.; Jacobi, C.; Jansen, F. W.; Lacy, A.; Millat, B. \& Schwenk, W. (2002): European Association for Endoscopic Surgery clinical practice guideline on the pneumoperitoneum for laparoscopic surgery. Surg. Endosc., 16: 11211143.

Reid, J. ; Nolan, A. M. and Welsh, E.(1993):Protocol as an induction agent in the goat: a pharmacokinetic study. J Vet PharmacolTher. 16(4):488-93.

Tighe M. and Brown H.(2003): Clinical Chemistry. In Mosby Comprehensive Review for Veterinary Technicians $2^{\text {nd }}$ Chapter (6)98-99. 


\section{الملخص العربي}

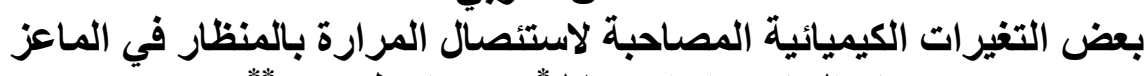

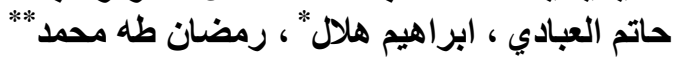

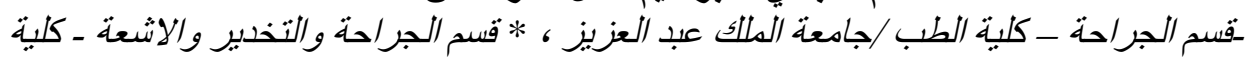
الطب البيطري/ جامعة قناة السويس ** قسم الباثولوجيا الاكلينيكيةـ كلية الطب البيطري/ جامعة قناة السوبيس

أصبحت طريقة استئصسال المر ارة بالمنظار تستخدم على نطاق واسع في كلا من الإنسان و الحيوان

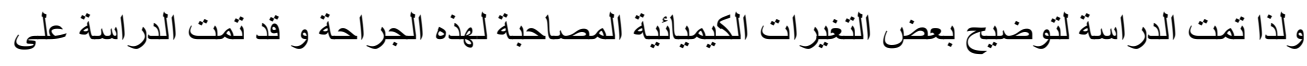

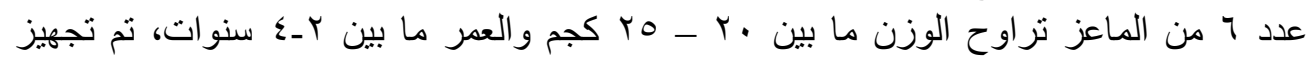

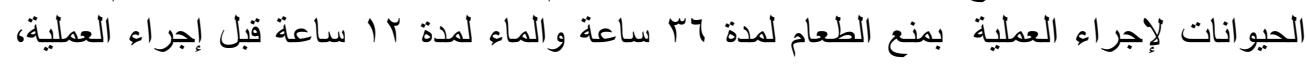

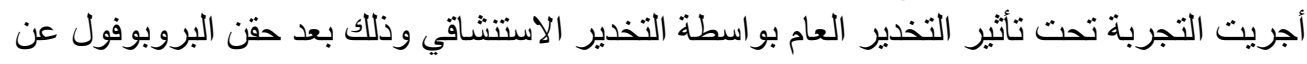

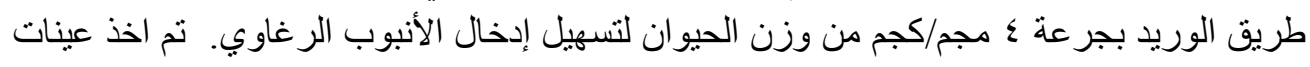

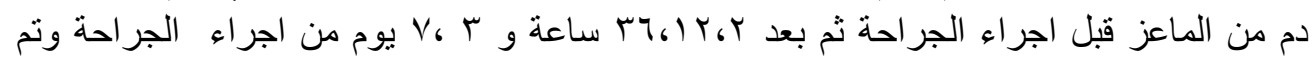

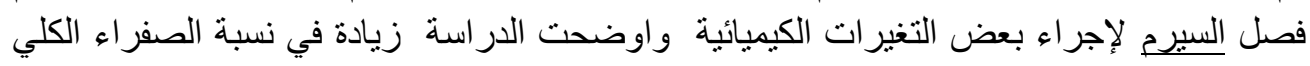

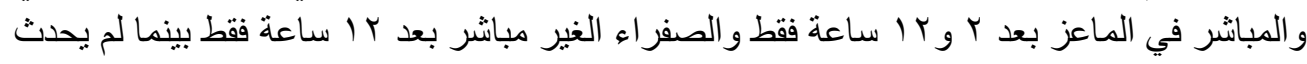

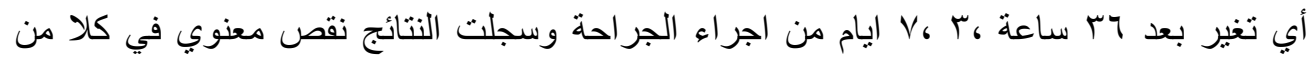

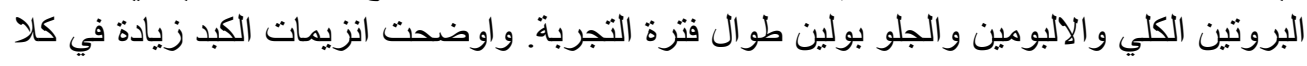

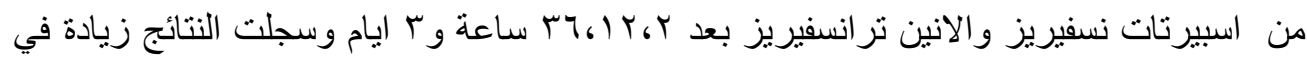

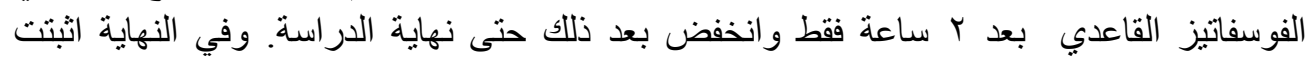

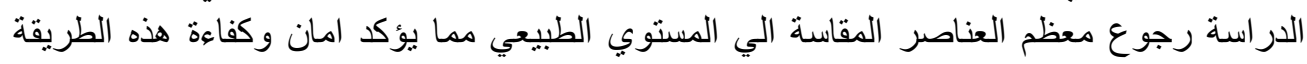
دون حدوث أب مخاطر على الحيوان. 